\title{
How the Outcome of Infants with Low and Moderate Risks of Vesicoureteral Reflux Differs when They are Managed Conservatively or Operated?
}

\author{
Düşük ve Orta Riskli Vezikoüreteral Reflüsü Olan Çocukların Takip veya Opere Edildiğindeki \\ Sonuçları Nasıldır?
}

\author{
(D) Burak Çıtamak, (1) Hasan Serkan Doğan, (D) Taner Ceylan, (D) Hakan Bahadır Haberal, (D) Meylis Artykov, (D) Berk Hazır, (D) Serdar Tekgül \\ Hacettepe University Faculty of Medicine, Department of Urology, Ankara, Turkey
}

\section{Abstract}

Objectives: To compare the resolution of reflux after surgery and follow-up and to determine what the appropriate treatment is in patients with vesicoureteral reflux (VUR) who were diagnosed less than 2 years of age.

Materials and Methods: Data from 250 patients who were diagnosed with VUR below 2 years of age between 2000 and 2016 were examined retrospectively. Patients with low risk and moderate risks according to the EAU/ESPU guidelines were evaluated. Patients who underwent surgery and followed up were compared regarding the age at diagnosis, VCUG findings, gender, presence of scar in DMSA, BTI, postoperative UTI, follow-up period and resolution rates.

Results: Of the patients, 207 patients underwent surgery while 43 did not. Mean age was 9.62 (0-24) months. Follow-up patients were followed up for an average of 55.4 months. Of the followed-up patients, 60.5\% (26) had complete resolution of VUR at the average of 25.8 months (6-64). When we compared the data of surgically treated and followed-up patients, we detected that frequency of male gender, renal scar, high-grade reflux and moderate risk were significantly more, the resolution rate was higher and follow-up period was shorter in operated group.

Conclusion: Spontaneous resolution rate of VUR less than 2 years of age is high and it is important to determine which patients should undergo early surgery in this patient group in terms of preventing complications. Surgical options with satisfactory success rates should be discussed with the family. Besides, the possible costs and comorbidities should also be regarded.

Key Words: Vesico-ureteral Reflux, Ureteroneocystostomy, Subureteric Injection, Urinary Tract Infections

\section{Öz}

Amaç: İki yaş altı tanı konan vezikoüreteral reflü (VUR) hastalarında cerrahi ve takip hastalarının başarılarını karşılaştırarak, bu hasta grubunda uygun tedavinin ne olduğunu ortaya koymaktır.

Gereç ve Yöntem: 2000-2016 tarihleri arasında 2 yaş altında VUR tanısı olan, EAU/ESPU kılavuzlarına göre düşük ve orta riskli olan ve tüm datasına ulaşılan 250 hastanın verileri retrospektif olarak incelendi. Hastaların tanı anındaki yaşları, VCUG verileri, cinsiyeti, DMSA bulgularında skar olup olmadığı, araya giren enfeksiyon, postoperatif idrar yolu enfeksiyonu, takip süreleri ve başarıları karşılaştırıldı.

Bulgular: Hastaların 43'ü cerrahi işlem olmadan takip edilmiş, 207'si ise cerrahi işlem geçirmiştir. Hastaların ortalama yaşı 9,62 (0-24) ay bulundu. Takip hastaları ortalama 55,4 ay takip edildi. Takipteki hastaların \%60,5'inde (26) VUR ortalama 25,8 ayda (6-64) tam rezolüsyona uğradı. Cerrahi olarak tedavi edilen ve takip edilen hastaların verilerini karşılaştıııldığında, opere edilen grupta, erkek cinsiyet, böbrek skarı, yüksek dereceli reflü ve orta risk varlığının anlamlı derecede daha fazla olduğu, reflünün çözünme oranının yüksek olduğu ve takip süresinin daha kısa olduğu tespit edildi. Sonuç: İki yaş altında VUR tanısı alan hastaların spontan rezolüsyon oranı yüksek olup, bu hasta grubunda hangi hastanın erken dönemde cerrahi girişim yapılması gerektiği komplikasyonları önleme açısından önemlidir. Cerrahi seçenek ise tatmin edici başarı oranları ile mutlaka aile ile tartışılmalı ancak olası maliyet ve komorbiditeleri de unutulmamalıdır.

Anahtar Kelimeler: Vezikoüreteral Reflü, Üreteroneosistostomi, Subüreterik Enjeksiyon, Idrar Yolu Enfeksiyonu

Address for Correspondence/Yazışma Adresi: Spc. Dr. Burak Çıtamak,

Hacettepe University Faculty of Medicine, Department of Urology, Ankara, Turkey

E-mail: burakcitamak@gmail.com ORCID: orcid.org/0000-0002-7341-8753

Received/Geliş: 02.12.2019 Accepted/Kabul: 21.02.2020

๑Copyright 2020 Ankara University Faculty of Medicine

Journal of Ankara University Faculty of Medicine is published by Galenos Publishing House.

All content are under CC BY-NC-ND license. 


\section{Introduction}

Vesicoureteral reflux (VUR) is an important disease that can lead to serious health problems such as nephropathy, hypertension and renal failure. However, the morbidity of reflux has decreased significantly due to modern understanding of the pathophysiology and natural course of the disease, the rational application of different anti-reflux procedures and continuous antibiotic prophylaxis (CAP) (1). Due to the fact that VUR is more likely to have spontaneous resolution under 2 years of age, primary option is to follow these patients without surgery (2). Considering these factors, the European Association of Urology (EAU)/ European Society for Paediatric Urology (ESPU) risk classification was established to determine the candidates for follow-up and surgery (3). The aim of this study is to compare the outcome of surgery and follow-up in terms of resolution of reflux; and to analyze factors for the selection of the appropriate treatment in our patient cohort with VUR who were diagnosed below 2 years of age.

\section{Materials and Methods}

Data from 250 patients who were diagnosed with VUR below 2 years of age between 2000 and 2016 were examined retrospectively. Patients with neurogenic bladder, double collecting system, mega-ureter and irregular follow-up were excluded. Voiding cystourethrographies (VCUG) were graded according to the International Reflux Study Committee as "low grade" for grades 1, 2 and 3 and "high grade" for grades 4 and 5 (4). Renal scarring was evaluated by dimercaptosuccinic acid (DMSA) scintigraphy. Then, the patients were separated into two groups as those with low risk and those with moderate risk according to the EAU/ESPU guidelines. The reflux of patients who did not undergo surgical intervention was re-evaluated by repeated VCUGs. During follow-up, VCUG was performed according to the patients' clinical courses.

Our initial management policy for VUR that is diagnosed in infant period is to start the CAP. Febrile urinary tract infection (UTI), worsening VUR state or new onset renal scars on DMSA under CAP were indications for surgical intervention.

The decision of type of the surgery was given intraoperatively. The appearance of ureteric orifice was the main indicator of the type of the surgery. The significantly incompetent orifice (golf hole orifice) appearance directed us to open ureteral reimplantation whereas endoscopic subureteric injection (STING) was the preferred technique in cases with relatively more competent orifices. For the patients with failed previous STING procedure, we observed the cystoscopic appearence of the orifice. A repeat STING was performed if the injected material seems to be migrated. On the other hand, open surgery was the method of choice if reflux was persisting despite the preserved mound appearence under the orifice that means endoscopic method has been ineffective.

Indications for the surgery were recorded for surgically treated patients. Surgical procedures were as ureteroneocystostomy (UNC) and STING. For evaluation of surgical outcome, VCUG or clinical improvement (if control VCUG was not performed) was taken into consideration. Patients continued to receive prophylaxis for 3 months after surgery.

This study was approved by the Hacettepe University Local Ethical Committee (G0-17/106). Of the patients, age at diagnosis, VCUG findings, gender, presence of scar in DMSA scintigraphy, breakthrough infection (BTI), postoperative UTI, follow-up period and resolution rates were compared. MannWhitney, chi-square, t-test and Kaplan-Meier survival analysis in SPSS 17.0 package program were used for statistical analysis.

\section{Results}

Of the 250 patients, 207 patients underwent surgery while 43 did not. Mean age at diagnosis was $9.62(0-24)$ months and mean follow-up period was 34.09 (6-182) months. Male/female ratio was $128 / 122$ and VUR was bilateral in 143 patients while unilateral in 107. Renal scar was present in 133 patients (53.2\%) and 63 patients (25.2\%) were in EAU-low risk group (low grade reflux without cortical abnormalities) while 187 patients (74.8\%) were in EAU-moderate risk group (symptomatic or asymptomatic patients with high grade reflux with or without cortical abnormalities; low grade reflux with renal cortical abnormalities) (3). Low grade and high grade VUR were present in $99(39.6 \%)$ and $151(60.4 \%)$ patients, respectively. Patients characteristics are shown in Table 1.

Of the surgically-treated patients, STING and UNC were performed in $141(68.1 \%)$ and $66(31.9 \%)$ with the resolution rates of $69.7 \%$ and $91.5 \%$, respectively. The overall resolution rate of surgical interventions was $83.2 \%$. Previous STING history was present $16.4 \%(34 / 207)$ in surgically treated patients. Of these 34 patients two underwent UNC and three underwent repeat STING procedure. In the surgical group, success was associated with grade of VUR (low vs high grade VUR, $77.1 \%$ vs 88.3\%, $p=0.036$ ) and surgical method (UNC vs STING, $p=0.001$ ) in univariate analysis and multivariate analysis revealed the single predictor factor was the surgical method. Mean time interval between diagnosis and surgery was 16.2 (0-79) months. Factors affecting reflux resolution rate after UNC were presence of high-grade VUR (low vs high grade VUR, $80.8 \%$ vs $93.9 \%$, chi-square test, $p=0.030$ ) and moderate-risk according (low risk vs moderate risk $72.7 \%$ vs $93.8 \%$, chi-square test, $\mathrm{p}=0.020$ ) to the EAU risk classification. No affecting factor was detected for reflux resolution after STING procedure. Although being 
statistically insignificant, resolution rates after STING procedure had a tendency to be different between patients with low and moderate risk and those with low and high-grade VUR (low vs moderate risk, $80 \%$ vs $61 \%, p=0.096$ and low vs high grade VUR, $75 \%$ vs $59.1 \%, p=0.185)$. In surgically-treated patients, indications for surgery were multiple BTIs, family choice and high-grade VUR and/or scars in 11.6\% (24), 15\% (31) and 73.4\%, respectively. The risk group was not found to have an effect on surgical success rates.

In follow-up patients, mean number of VCUG was 2.35 (27) and mean follow-up period was 55.4 months. In follow-up group, VUR have reduced in grade or completely regressed in 33 (76.7\%). Complete spontaneous resolution of VUR was detected in $26(60.5 \%)$ of the follow-up patients at an average of 25.8 (6-64) months (Figure 1). Patients with spontaneous resolution had a longer follow-up period (30.8 vs 62.8 months, $p=0.016$ ). In follow-up group, the single predictor for spontaneous resolution was the reflux grade (grade $1-2$ vs grade 3 vs grade $4-5,92.9 \%$ vs

\begin{tabular}{ll}
\hline Table 1: Patient characteristics & \\
\hline & Patients \\
\hline Resolution rate & $80.4 \%(201)$ \\
\hline $\begin{array}{l}\text { Mean age (months) } \pm \text { standard } \\
\text { deviation }\end{array}$ & $9.62 \pm 6.41(0-24)$ \\
\hline $\begin{array}{l}\text { Gender (F/M) } \\
\text { Bilateral VUR }\end{array}$ & $122 / 128(48.8 \% / 51.2 \%)$ \\
\hline $\begin{array}{l}\text { Presence of scar in DMSA } \\
\text { High-grade VUR }\end{array}$ & $57.2 \%(143)$ \\
\hline $\begin{array}{l}\text { EAU risk, Low / moderate risk } \\
\text { Mean follow-up (months) } \pm \text { standard }\end{array}$ & $33.2 \%(133)$ \\
deviation & $60.8 \%(152)$ \\
\hline $\begin{array}{l}\text { F: Female, M: male, VUR: Vesicoureteral reflux, DMSA: Dimercaptosuccinic acid, EAU: } \\
\text { European Association of Urology }\end{array}$
\end{tabular}

$42.9 \%$ vs $46.7 \%, p=0.009$ ). Spontaneous resolution rate of low and moderate risk patients were $63.6 \%$ and $57.1 \%$ respectively ( $p=0.663)$.

When the data of surgical and follow-up patients were compared, there were statistically significant differences between resolution rate, gender, presence of scar in DMSA, presence of high-grade VUR, EAU risk classifications and followup periods (Table 2).

\section{Discussion}

The standard treatment for reflux that was diagnosed in early infancy is CAP as spontaneous resolution of VUR is possible because anatomic abnormalities or the functional problems may improve as the child grows. In a study of Estrada et al. (5), spontaneous resolution has been shown to depend on the age at the onset, gender, grade of reflux, laterality, clinical

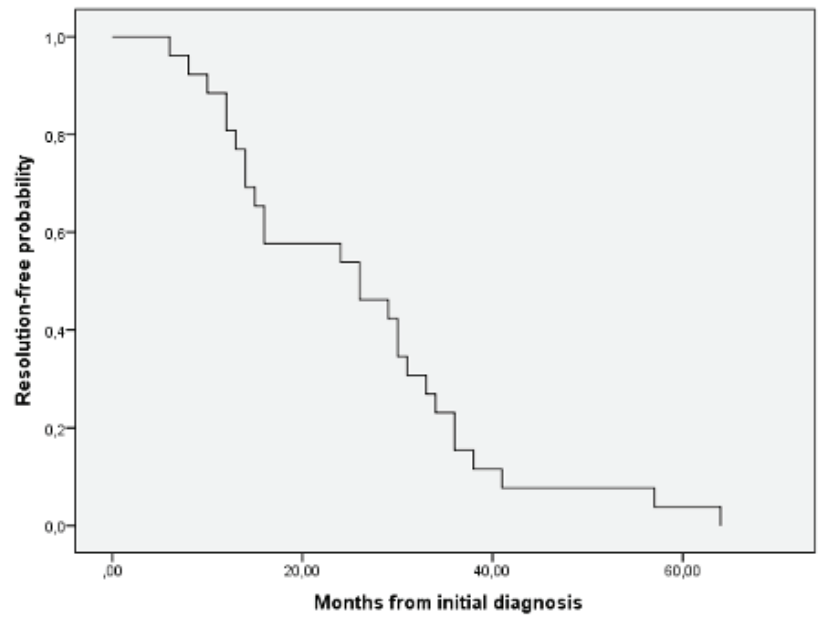

Figure 1: Resolution of VUR in follow-up patients VUR: Vesicoureteral reflux

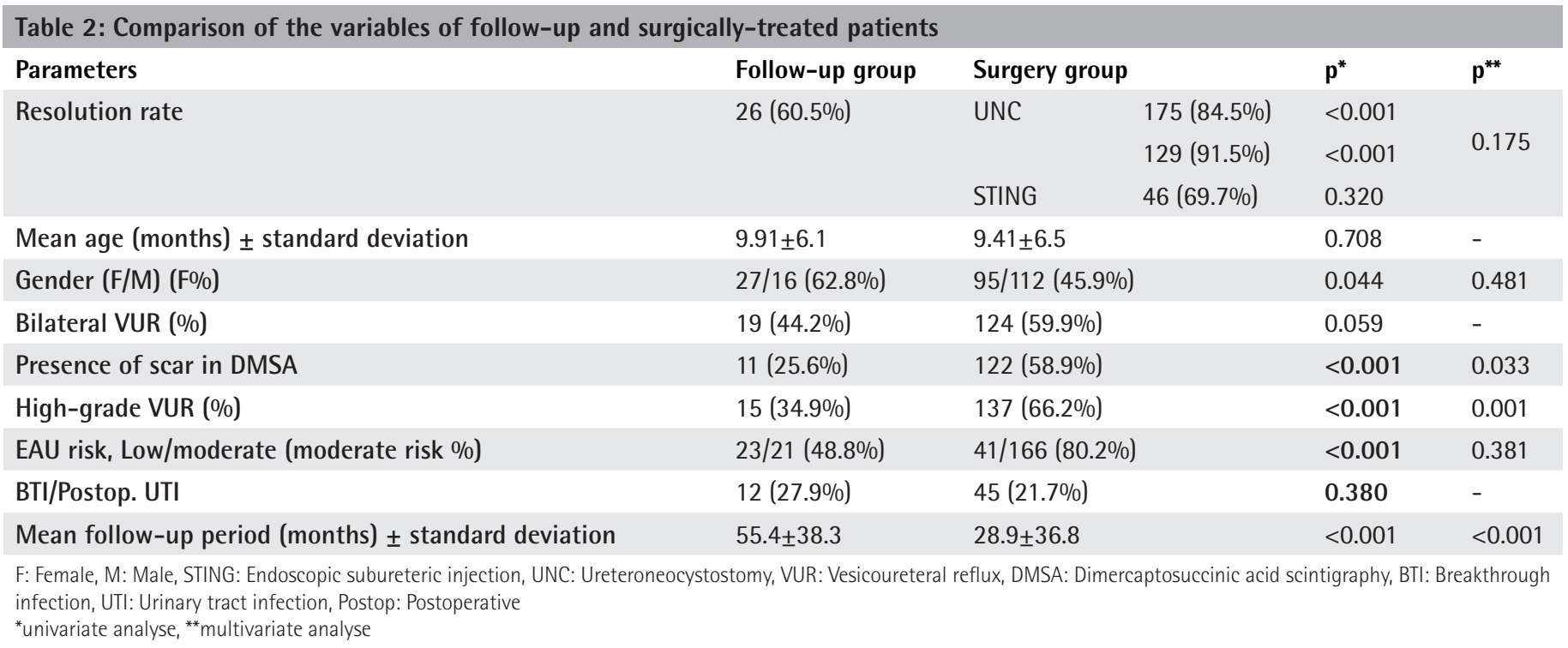


presentation and ureteral anatomy. Besides, Knudson et al. (6) found that grade of reflux, presence of prenatal hydronephrosis and bladder capacity at the onset were effective on spontaneous resolution in patients who were diagnosed with VUR below 2 years of age. In our study, lower grade of VUR was found to be the most favorable factor in spontaneous resolution. Similarly, this patient group may have a different clinical course than the others due to voiding dysfunction and unimproved voiding habits.

Surgical correction of VUR is an effective method with success rates of over $90 \%$ and over $70 \%$ for open and endoscopic techniques, respectively (7-9). Today, the contemporary approach in this young age group is conservative follow-up however patients with lesser resolution rates and those who failed in conservative follow-up are directed to the surgical options. The choice of surgical method usually depends on the orifice configuration, previous surgical history, presence of bladder pathologies and parental preference.

Because of the considerable spontaneous resolution chance, risk of anesthesia and technical issues particularly in very young children, surgery is not the primary treatment option for every reflux patient. Despite the fact that spontaneous resolution is high there will be a group of patients who would require antireflux surgery because of multiple BTIs, family choice and high grade of VUR and/or presence of scar (11.6\%, 15\% and 73.4\% respectively in our patient group). Generally, surgically-treated patients have high-grade of VUR and/or scarred kidneys and they are less likely to have spontaneous resolution (10). In these patients, the risk for renal scarring is high during the long follow-up period. Additionally, because of the possibly long follow-up period needed for spontaneous resolution and higher rate of success that the surgical treatment promises within a short period of time, families frequently favor surgery.

For 5 year of follow-up, spontaneous resolution rate of VUR is $80 \%$ for grade $1-2$ reflux while $30-50 \%$ for grade $3-5$ reflux and is lower for bilateral reflux (2). In our series, resolution rate for the follow-up patients was $60.5 \%$. The resolution rate in the surgical patients was higher than those who are followed-up. Another feature of the follow-up and surgical patients was the presence of more male patients in the surgical group. It may be due to the higher frequency of urinary tract infections and higher grade of reflux in male patients in this age ( $<2$ years) group $(11,12)$.

In some studies, it was reported that spontaneous resolution of VUR is higher in younger patients $(10,13,14)$. Similarly, the rate of resolution was found to be higher in patients diagnosed before 2 years old than those after 2 years old (6). Our main reason of including patients especially who were diagnosed before 2 years old is to determine the difference between spontaneous resolution and surgical success and to find out which patients should be followed-up. We detected that high grade VUR is an unfavorable factor for spontaneous resolution. Besides, presence of scar and high-grade VUR was more frequent in surgically treated group.

The EAU/ESPU guidelines help us to determine which of the two main treatment options (conservative follow-up and surgery) is appropriate for which patient in order to avoid the potential complications and morbidity of VUR (3). In this guideline, patients were separated into three groups as low, moderate and high risk according to presentation, laterality, presentational age, grade of VUR, gender, anatomical abnormalities and presence of scarring and voiding dysfunction. The guidelines recommend more aggressive follow-up and state that possibility of intervention is more likely in high-risk patients (15), in our study, we included low and moderate risk groups to provide more homogenous groups and aimed to understand the course of the disease in these grey zone patients. In the moderaterisk group, surgery can be planned according to clinical course and deterioration during follow-up. In our study, $48.8 \%$ of the follow-up patients were in moderate-risk group while the rate was $80.2 \%$ for the surgical patients. Moderate-risk patients who were diagnosed under 2 years of age have a lower spontaneous resolution rate and the rate of surgery is higher.

Follow-up duration was shorter in the surgery group $(55.4 \pm 38.3$ vs $28.9 \pm 36.8$ months). It is an expectable finding to have a longer follow-up period in non-surgical group. Many patients may drop out from the follow-up after a successful surgery despite the fact that they are advised for routine follow-up.

\section{Study Limitations}

The limitations of our study were the retrospective nature and non-randomized patient selection. As the nature of retrospective studies, we were not able to access the complete data of all the patients due to the discordance of some patients to the follow-up protocol. The discordance between the numbers of patients in two groups may be attributed as a limitation. As we are surgical department, the number of patients those were referred for surgery was higher as anticipated. The family choice for surgery can especially affect patient distribution. Because of the missing data for longer follow up and DMSA findings, our outcome analysis is based on resolution of reflux.

\section{Conclusion}

Spontaneous resolution rate of VUR in patients under 2 years of age is high and it is important to determine which patients should undergo early surgical intervention in this patient group in terms of preventing complications. When we compared follow-up and surgically treated groups, we detected that male gender, presence of scar, high grade VUR and moderate risk was 
significantly more frequent in operated group in univariate analysis where presence of renal scar and high grade VUR were the most significant factor for surgery in multivariate analysis. Most of the infants with VUR are managed by conservative approach and our findings give clues to predict the patient groups who are under risk of having surgery.

\section{Ethics}

Ethics Committee Approval: This study is approved by Hacettepe University Ethics Committee (G0-17/106).

Informed Consent: Informed consent was obtained from all the patients are including to this study.

Peer-review: Externally peer-reviewed.

\section{Authorship Contributions}

Surgical and Medical Practices: B.Ç., H.S.D., S.T., Concept: B.Ç., H.S.D., S.T., Design: B.Ç., H.S.D., S.T., Data Collection or Processing: B.Ç., T.C., H.B.H., M.A., B.H., Analysis or Interpretation: B.Ç., H.S.D., Literature Search: B.Ç., H.S.D., S.T., Writing: B.Ç., T.C., H.S.D.

Conflict of Interest: No conflict of interest was declared by the authors.

Financial Disclosure: The authors declared that this study received no financial support.

\section{References}

1. Hoberman, A., R.W. Chesney and R.T. Investigators, Antimicrobial prophylaxis for children with vesicoureteral reflux. N Engl J Med, 2014. 371: p. 10721073.

2. Elder, J.S., C.A. Peters, B.S. Arant, Jr., et al., Pediatric Vesicoureteral Reflux Guidelines Panel summary report on the management of primary vesicoureteral reflux in children. J Urol, 1997. 157: p. 1846-1851.
3. Tekgul, S., H. Riedmiller, P. Hoebeke, et al., EAU guidelines on vesicoureteral reflux in children. Eur Urol, 2012. 62: p. 534-542.

4. Lebowitz, R.L., H. Olbing, K.V. Parkkulainen, et al., International system of radiographic grading of vesicoureteric reflux. International Reflux Study in Children. Pediatr Radiol, 1985. 15: p. 105-109.

5. Estrada, C.R., Jr., C.C. Passerotti, D.A. Graham, et al., Nomograms for predicting annual resolution rate of primary vesicoureteral reflux: results from 2,462 children. J Urol, 2009. 182: p. 1535-1541.

6. Knudson, M.J., J.C. Austin, Z.M. McMillan, et al., Predictive factors of early spontaneous resolution in children with primary vesicoureteral reflux. J Urol, 2007. 178(4 Pt 2): p. 1684-1688.

7. Elder, J.S., M. Diaz, A.A. Caldamone, et al., Endoscopic therapy for vesicoureteral reflux: a meta-analysis. I. Reflux resolution and urinary tract infection. J Urol, 2006. 175: p. 716-722.

8. Routh, J.C., B.A. Inman and Y. Reinberg, Dextranomer/hyaluronic acid for pediatric vesicoureteral reflux: systematic review. Pediatrics, 2010. 125: p. 1010-1019.

9. Duckett, J.W., R.D. Walker and R. Weiss, Surgical results: International Reflux Study in Children--United States branch. J Urol, 1992. 148(5 Pt 2): p. 1674-1675.

10. Sjostrom, S., U. Sillen, U. Jodal, et al., Predictive factors for resolution of congenital high grade vesicoureteral reflux in infants: results of univariate and multivariate analyses. J Urol, 2010. 183: p. 1177-1184.

11. Sjostrom, S., U. Sillen, M. Bachelard, et al., Spontaneous resolution of high grade infantile vesicoureteral reflux. J Urol, 2004. 172: p. 694-8; discussion 699.

12. Hansson, S., I. Bollgren, E. Esbjorner, et al., Urinary tract infections in children below two years of age: a quality assurance project in Sweden. The Swedish Pediatric Nephrology Association. Acta Paediatr, 1999. 88: p. 270274.

13. Papachristou, F., N. Printza, D. Kavaki, et al., The characteristics and outcome of primary vesicoureteric reflux diagnosed in the first year of life. Int J Clin Pract, 2006. 60: p. 829-834.

14. Schwab, C.W., Jr., H.Y. Wu, H. Selman, et al., Spontaneous resolution of vesicoureteral reflux: a 15-year perspective. J Urol, 2002. 168: p. 25942599. 